\title{
Pengaruh Kompetensi Dosen Dan Motivasi Belajar Terhadap Kemampuan Analisis Statistika Mahasiswa Ftik IAIN Kendari
}

\author{
Abdul Kadir \\ Fakultas Tarbiyah dan Ilmu Keguruan Institut Agama Islam Negeri Kendari, Indonesia \\ abdir_edu@yahoo.co.id
}

\begin{abstract}
This research aims to find out how lecturers' competence and learning motivation affect the students' statistical analysis ability. This research was carried out at FTIK IAIN Kendari academic year 2016/2017. Population and sample is focused on the 54 students who have successfully passed the statistics and research methodology course. The instruments used are tests, questionnaires and documentation study. Data analysis techniques used are descriptive and inferensial analysis after the test meets the requirements of linearity, multicollinearity, normality and autocorrelation continued with the hypothesis testing through multiple linear regression analysis and path analysis. The research results indicate that; 1) the lecturers' competence partially affecrs the students' inferential statistics analysis capabilities significantly, 2) the students' learning motivation partially affects the students' inferential statistics capability significantly, and 3) the lecturers' competence and the students' motivation significantly affect the students' inferential statistics capabilities. Both of these variables contribute collectively as much as $62.2 \%$ to the students' inferential capability, while the rest $37.8 \%$ influenced or described by other factors which are not addressed in this study.
\end{abstract}

\section{Keywords: competence of professors, motivation to learn and the ability of analysis statistics inferensial}

\begin{abstract}
Abstrak
Penelitian ini dimaksudkan untuk mengetahui seberapa besar kompetensi dosen dan motivasi belajar berpengaruh terhadap kemampuan analisis statistika mahasiswa. Penelitian ini dilaksanakan di FTIK IAIN Kendari pada mahasiswa semester VI Program Studi Pendidikan Agama Islam Tahun Akademik 2016/2017. Populasi dan sampel difokuskan kepada 54 orang mahasiswa yang telah lulus mata kuliah statistika dan metodologi penelitian. Instrumen yang digunakan adalah tes, kuesioner dan studi dokumentasi. Teknik analisis data yang digunakan adalah analisis deskriptif dan inferensial setelah memenuhi uji persyaratan normalitas, lineariitas, multikolinearitas dan autokorelasi dilanjutkan dengan pengujian hipotesis melalui analisis regresi linear berganda dan path analysis. Hasil penelitian menunjukan bahwa kompetensi dosen secara parsial berpengaruh signifikan terhadap kemampuan analisis statistika inferensial mahasiswa. Motivasi belajar secara parsial juga berpengaruh signifikan terhadap kemampuan analisis statistika inferensial mahasiswa. Dengan demikian maka ompetensi dosen dan motivasi belajar secara simultan berpengaruh signifikan terhadap kemampuan analisis statistika inferensial mahasiswa. Kedua variabel tersebut memberikan kontribusi secara bersama-sama sebesar $62,2 \%$, sedangkan sisanya sebesar 37,8\% dipengaruhi atau dijelaskan oleh faktor lain yang tidak dibahas dalam penelitian ini.
\end{abstract}

\section{Kata kunci: kompetensi dosen, motivasi belajar, analisis statistik inferensial}

\section{A. Pendahuluan}

Proses pembelajaran di perguruan tinggi, dosen atau pendidik sering menghadapi masalah dengan adanya mahasiswa-mahasiswa yang mengalami kesulitan belajar. Pada umumnya masalah yang dihadapi para dosen di pergruan tinggi adalah gejala atau manifestasi adanya kesulitan belajar yang ditampakkan dalam bentuk-bentuk perilaku tertentu oleh mahasiswa, seperti halnya pada mata kuliah statistik. 
Rendahnya kemampuan statistika mahasiswa dapat dilihat dari penguasaan mahasiswa terhadap materi yang diberikan. Untuk mengetahui penguasaan mahasiswa terhadap materi tersebut, salah satunya dengan memberikan tes atau soal tentang materi tersebut. Kesalahan mahasiswa dalam mengerjakan soal dapat menjadi salah satu petunjuk untuk mengetahui sejauh mana mahasiswa menguasai materi yang diberikan. Oleh karena itu, adanya kesalahankesalahan tersebut perlu diidentifikasi dan dicari faktor-faktor apa saja yang mempengaruhinya dan kemudian dicari solusinya.

Berdasarkan pengalaman penulis memberikan kuliah statistika di Fakultas Tarbiyah dan Ilmu Keguruan (FTIK) IAIN Kendari adalah bahwa pelajaran statistika merupakam mata kuliah yang kurang diminati dan dianggap yang sulit dan membosankan oleh mahasiswa. Hal ini didasarkan karena materinya lebih banyak yang bersifat menghitung dan menalar. Bagi mahasiswa yang memiliki kemampuan kuantitatif yang rendah, maka mata kuliah ini menjadi mata kuliah yang tidak menarik. Akibatnya minat dan motivasi belajar mahasiswa terhadap mata kuliah ini menjadi rendah.

Mahasiswa yang menempuh kuliah di FTIK memiliki latar belakang pendidikan yang sangat bervariasi, yakni; beberapa mahasiswa yang berasal dari SMA, MA, dan SMK dengan latar belakang jurusan yang berbeda pula, ada jurusan IPA, Agama, maupun IPS dan dari SMK dengan berbagai jurusan. Input yang demikian beragam menyebabkan terjadinya perbedaan penelaan materi oleh mahasiswa. Perbedaan kemampuan intelegensi mahasiswa khususnya dalam mata kuliah statistika sangat bervariasi. Kemampuan ini menyangkut kemampuan untuk mendefinisikan, memahami, mengidentifikasi, memecahkan masalah dan masih banyak lagi. Berbagai hal yang menyangkut mahasiswa itu juga berkembang bersama lingkungan belajarnya, baik yang langsung dirasakan mahasiswa maupun yang tidak secara langsung. Metodologi dan segala aspek pembelajaran yang diciptakan dosen, bahan ajar, sumber belajar, media dan situasi kelas juga membantu memberikan dorongan maupun hambatan dalam belajar mahasiswa.

Hasil wawancara penulis dengan mahasiswa program studi Pendidikan Agama Islam (PAI) semester VII, bahwa mahasiswa mengalami kesulitan dalam mempelajari mata kuliah statistika dan metode penelitian kuantitatif, mereka menganggap mata kuliah statistik dengan analisis inferensial adalah sulit sekali dipahami, penuh dengan rumus-rumus, perhitungan dan perlu pemahaman juga penalaran yang tinggi, selain itu dosen juga yang mengajar belum tuntas menjelaskan materi tentang prosedur pengolahan data dan analisis inferensial. ${ }^{1}$

Ahmadi menyatakan bahwa setiap individu memang tidak ada yang sama. Perbedaan individual ini pulalah yang menyebabkan perbedaan tingkah laku belajar dikalangan anak didik dalam keadaan dimana anak didik tidak dapat belajar sebagaimana mestinya, itulah yang disebut dengan kesulitan belajar. ${ }^{2}$ Hal ini menjadi salah satu kendala dalam proses pembelajaran. Sebagian besar mahasiswa merasa masih kesulitan dalam mengikuti proses pembelajaran yang diberikan yang mengakibatkan kemampuan dalam penguasaaan materi pun sangat kurang.

Keterbatasan kemampuan analisis statistika inferensial mahasiswa sangat berkaitan dengan pelakasanaan perkuliahan di kelas yang dilakukan oleh dosen. Proses pembelajaran akan berjalan dengan lancar bila disertai minat karena minat merupakan alat motivasi utama yang dapat membangkitkan semangat belajar mahasiswa dalam rentang waktu tertentu. ${ }^{3}$

Selain faktor motivasi belajar mahasiswa yang dapat mendukung tingkat pemahaman terhadap pembelajarannya, terdapat faktor yang tidak kalah pentingnya adalah kompetensi yang dimiliki oleh dosen dalam melaksanakan perkuliahan. Ahmadi mendefinisikan bahwa hasil belajar yang dicapai seseorang merupakan hasil interaksi berbagai faktor yang

\footnotetext{
${ }^{1}$ RHS, Mahasiswa semester VII Program Studi PAI, Wawancara. Tanggal 12 Desember 2016

${ }^{2}$ Abu Ahmadi dan Supriyono, Psikologi Belajar. (Jakarta: Rineka Cipta, 2008), h.77

${ }^{3}$ Djamarah dan Aswan Zain. Strategi Belajar Mengajar. (Jakarta: Rineka Cipta, 2006)
} 
mempengaruhinya baik dari dalam diri (faktor internal) maupun dari luar (faktor eksternal) individu. ${ }^{4}$

Berdasarkan teori di atas, motivasi belajar adalah faktor yang berpengaruh terhadap kemampuan analisis inferensial dipandang dari sudut faktor internal, sedangkan kompetensi dosen merupakan faktor yang berpengaruh terhadap kemampuan analisis inferensial dipandang dari sudut faktor eksternal. Kedua faktor tersebut saling berinteraksi satu sama lain secara langsung maupun tidak langsung dalam mempengaruhi hasil belajar atau tingkat kemampuan belajar yang akan dicapai mahasiswa.

Dosen memiliki peranan kunci dalam setiap upaya peningkatan mutu, relevansi, dan efisiensi pendidikan. Hal tersebut menuntut dosen untuk mampu mempersiapkan kompetensi dirinya secara optimal, karena bagaimanapun kompetensi dosen mencerminkan kinerja dosen atau kemampuan dalam mengajar di kelas sehingga dapat dipastikan semakin baik kompetensi yang dimiliki dosen, maka sangat memungkinkan prestasi akademik mahasiswanya dapat meningkat. Dengan demikian, maka dosen dituntut untuk memiliki kompetensi dalam menjalankan tugas sebagai pendidik yang professional, sehingga kemampuan akademik mahasiswa dapat tercapai sesuai tujuan yang diharapkan. Artikel ini ditulis dalam upaya untuk melakukan analisis tentang Pengaruh kompetensi dosen dan motivasi belajar terhadap kemampuan analisis statistik inferensial mahasiswa di FTIK IAIN Kendari.

\section{B. Kompetensi Dosen}

Dosen yang berkompeten pada umumnya dilihat dari seberapa jauh dosen menguasai materi dan dosen tersebut dapat menerapkan model pembelajaran yang tepat untuk materi yang dipelajari. Menurut Djamarah, pendidik yang berkompeten adalah pendidik yang memiliki keterampilan memberi penguatan, bertanya, mengadakan variasi, menjelaskan, dan membuka dan menutup pelajaran. ${ }^{5}$

Menurut Muhibbin Syah, kompetensi adalah kemampuan, kecakapan, keadaan berwenang, atau memenuhi syarat menurut ketentuan hukum. ${ }^{6}$ Pengertian lain terdapat pada Undangundang No. 14 Tahun 2005, bahwa kompetensi adalah seperangkat pengetahuan, keterampilan, dan perilaku yang harus dimiliki, dihayati, dan dikuasai oleh guru dalam melaksanakan tugas keprofesionalan $^{7}$. Pemerintah telah merumuskan empat jenis kompetensi yang sesuai dengan perspektif kebijakan nasional. Keempat jenis kompetensi tersebut tercantum dalam Penjelasan Peraturan Pemerintah No. 19 Tahun 2005 tentang Standar Nasional Pendidikan, yaitu kompetensi pedagogis, kepribadian, sosial, dan profesional. ${ }^{8}$ Kompetensi dosen yang dimaksudkan meliputi kompetensi pedagogik, kompetensi, kepribadian, kompetensi sosial, dan professional.

Menurut Badan Standar Nasional Pendidikan, yang dimaksud kompetensi pedagogik adalah kemampuan dalam pengelolaan peserta didik yang meliputi; (a) pemahaman wawasan atau landasan kependidikan; (b) pemahaman tentang peserta didik; (c) pengembangan kurikulum/silabus; (d) perancangan pembelajaran; (e) pelaksanaan pembelajaran yang mendidik dan dialogis; (f) evaluasi hasil belajar; dan (g) pengembangan peserta didik untuk mengaktualisasikan berbagai potensi yang dimilikinya. ${ }^{9}$ Dosen tidak hanya mendidik mahasiswa di dalam kelas, namun juga diluar kelas. Mahasiswa memiliki rasa ingin tahu yang tinggi dan selalu mencoba hal-hal baru. Tugas dosen yaitu membantu perkembangan keingintahuan tersebut dan membuat mereka lebih ingin tahu.

\footnotetext{
${ }^{4}$ Abu Ahmadi dan Supriyono, Psikologi Belajar, h.138

${ }^{5}$ Syaiful Bahri. Djamarah, Psikologi Belajar. (Jakarta: Rineka Cipta, 2000), h.99

${ }^{6}$ Muhibbin Syah. Psikologi Pendidikan dengan Pendekatan Baru. (Bandung: Rosdakarya, 2004), h. 30

${ }^{7}$ Undang-Undang Nomor 14 Tahun 2005 tentang Guru dan Dosen

${ }^{8}$ Peraturan Pemerintah Nomor 19 Tahun 2005 tentang Standar Nasional Pendidikan

9 Jejen Musfah, Peningkatan Kompetensi Guru Melalui Pelatihan \& Sumber Belajar, Teori dan Praktik. (Yogyakarta: Prenada Media Group, 2017)...h. 31
} 
Kompetensi kepribadian merupakan kemampuan personal yang mencerminkan kepribadian yang mantap, stabil, arif, dan berwibawa serta dapat menjadi teladan peserta didik. Kompetensi kepribadian yaitu kemampuan kepribadian yang (a) berakhlak mulia; (b) mantap, stabil, dan dewasa; (c) arif dan bijaksana; (d) menjadi teladan; (e) mengevaluasi kinerja sendiri; (f) mengembangkan diri; dan (g) religius." 10

Kompetensi sosial merupakan kemampuan untuk berkomunikasi dan bergaul secara efektif dengan peserta didik, sesama pendidik, tenaga kependidikan, orang tua atau wali peserta didik, dan masyarakat sekitar. Kompetensi sosial merupakan kemampuan pendidik sebagai sebagian dari masyarakat untuk (a) berkomunikasi lisan dan tulisan; (b) menggunakan teknologi komunikasi dan informasi secara fungsional; (c) bergaul secara efektif dengan peserta didik, sesame pendidik, tenaga kependidikan, orang tua/wali peserta didik; dan (d) bergaul secara santun dengan masyarakat sekitar. ${ }^{11}$

Kompetensi profesional merupakan penguasaan materi pembelajaran secara luas dan mendalam yang mencakup penguasaan materi kurikulum mata pelajaran di sekolah dan substansi keilmuan yang menaungi materi serta penguasaan terhadap struktur dan metodologi keilmuannya. ${ }^{12}$ Menurut Musfah, kompetensi profesional adalah kemampuan penguasaan materi pembelajaran secara luas dan mendalam yang meliputi (a) konsep, struktur, dan metode kelilmuan yang menaungi dengan materi ajar; (b) materi ajar yang ada dalam kurikulum sekolah; (c) hubungan konsep antar mata pelajaran terkait; (d) penerapan konsep keilmuan dalam kehidupan sehari-hari; dan (e) kompetisi secara profesional dalam konteks global dengan tetap melestarikan nilai dan budaya nasional. ${ }^{13}$

Dengan demikian seluruh kompetensi dosen tersebut dalam praktiknya merupakan suatu kesatuan yang utuh terkait dengan tugas dan tanggung jawab profesionalnya sebagai pengajar, pembimbing, bahkan pembinaan hubungan dengan masyarakat, pengambangan kurikulum, dan pengembangan profesi. Dari penjelasan di atas dapat diambil sebuah kesimpulan bahwa kompetensi terarah pada tiga aspek yang harus dimiliki seorang dosen, yaitu pengetahuan, keterampilan, dan sikap. Tiga aspek tersebut saling berkaitan dan berpengaruh satu sama lain. Tentunya dapat diwujudkan dalam hasil kerja nyata sehingga dapat bermanfaat untuk diri sendiri serta mahasiswa, termasuk lingkungan sekitar.

\section{Motivasi Belajar}

Motivasi berasal dari bahasa inggris "motive" yang diambil dari kata asalnya motion yang berarti gerak atau sesuatu yang bergerak. Sedangkan menurut Sardiman, motive diartikan sebagai daya dan upaya yang mendorong seseorang untuk melakukan sesuatu. ${ }^{14}$ Selanjutnya menurut Gates, motivasi merupakan suatu kondisi fisiologis dan psikologis yang terdapat dalam diri seseorang yang mengatur tindakkannya dengan cara tertentu. ${ }^{15}$ Dari penjelasan tersebut dapat disimpulkan bahwa motivasi merupakan kondisi fisiologis dan psikologis yang terdapat dalam diri seseorang yang mendorongnya untuk melakukan aktivitas tertentu guna mencapai suatu tujuan tertentu.

Selanjutnya pengertian motivasi belajar menurut Dimyati dan Mudjiono bahwa motivasi belajar merupakan kekuatan mental yang mendorong terjadinya proses belajar. ${ }^{16}$ Sementara Winkel menyatakan motivasi belajar adalah keseluruhan daya penggerak psikis di dalam diri peserta didik yang menimbulkan kegiatan belajar, menjamin kelangsungan kegiatan belajar dan

\footnotetext{
${ }^{10}$ Jejen Musfah, Peningkatan Kompetensi Guru...h. 42

${ }^{11}$ Jejen Musfah, Peningkatan Kompetensi Guru...h. 53.

12 Yamin, Martinis, Sertifikasi Profesi Keguruan di Indonesia. (Jakarta: Gaung Persada Press, 2006), h. 19

13 Jejen Musfah, Peningkatan Kompetensi Guru ...hlm 54.

${ }^{14}$ Sardiman, A.M, Interaksi dan Motivasi Belajar Mengajar, (Jakarta: Rajawali Press, 2005), h.73

${ }^{15}$ Djaali. Psikologi Pendidikan..( Jakarta: PT. Bumi Aksara, 2008), h.101

${ }^{16}$ Dimyati dan Murdjiono, Belajar dan Pembelajaran. (Jakarta: PT. Rineka Cipta, 2009), h.85
} 
memberikan arah pada kegiatan belajar itu demi mencapai suatu tujuan. ${ }^{17}$ Sedangkan menurut Uno, motivasi belajar adalah dorongan internal dan eksternal pada siswa yang sedang belajar untuk mengadakan perubahan tingkah laku dan keberhasilan dalam belajar. ${ }^{18}$

Berdasarkan pendapat-pendapat tersebut dapat dikemukakan bahwa motivasi belajar adalah suatu penggerak yang timbul dari kekuatan mental diri mahasiswa maupun menciptakan suatu rangkaian usaha untuk mempersiapkan kondisi tertentu yang mengarahkan pada kegiatan belajar sehingga tujuannya dapat tercapai, sehingga dapat disimpulkan bahwa motivasi belajar siswa adalah keseluruhan daya gerak pada diri seseorang baik dari dalam dirinya (intrinsik) maupun dari luar dirinya (ekstrinsik). Indikator Intrinsik meliputi tingkat kedisiplinan mengikuti kuliah, ketekunan mengerjakan tugas, frekuensi mengikuti perkuliahan dan kemandirian dalam mengerjakan tugas; dan indikator ektrinsik berupa dorongan yang menimbulkan kegiatan belajar dan berprestasi.

\section{Kemampuan Analisis Statistika Inferensial}

Statistik inferensial juga sering dikenal dengan istilah statistik induktif, yaitu statistik yang menyediakan aturan atau metode yang dapat digunakan untuk membuat ramalan, membuat taksiran dan mengambil kesimpulan yang bersifat umum dari sekumpulan data (data sampel) yang dipilih secara acak dari saluruh data yang menjadi subyek kajian (populasi). ${ }^{19}$ Dengan demikian, statistik inferensial sifatnya lebih mendalam dan merupakan tindak lanjut dari statistik diskriptif. Statistik disktiptif merupakan dasar dari ilmu statistik secara keseluruhan. Oleh karena itu, untuk dapat mempelajari atau memahami statistik inferensial, seseorang harus terlebih dahulu mempelajari statistik diskriptif.

Analisis statistika inferensial digunakan untuk memprediksi apakah pola keteraturan yang tersedia dalam kelas sampel penelitian dapat berlaku pula dalam kelas populasi penelitian. Hubungan antar variabel atau korelasi antara dua variabel atau lebih dapat disajikan dalam bentuk model hipotesis secara umum, yaitu untuk model hipotesis yang memperlihatkan hubungan antar dua variabel atau lebih dapat disajikan dengan menggunakan bentuk persamaan regresi linear sederhana atau bentuk persamaan regresi linear berganda ${ }^{5}$. Besarnya sumbangan antar variabel dapat dilihat dari besarnya angka indeks korelasi antar variabel penelitian yang menjadi bahan kajian utama dalam suatu penelitian. ${ }^{20}$

Statistik inferensial terdiri atas dua macam, yaitu statistik parametrik dan statistik nonparametrik. ${ }^{21}$ Statistik parametrik adalah statistik yang distribusinya ditentukan dengan tepat jika distribusi populasinya diketahui, sedangkan statistik nonparametrik adalah statistik yang distribusinya dapat ditentukan tanpa mengetahui distribusi populasinya (bebas distribusi). Di dalam statistika parametrik biasanya diperlukan asumsi-asumsi antara lain populasinya harus berdistribusi normal, sehingga kesimpulan yang diambil memuat syarat kebenaran asumsi tersebut. Statistik nonparametrik asumsi tersebut diperlemah bahkan kadang-kadang tidak diperlukan. Kebanyakan dalam statistika nonparametrik sampelnya harus independen. Statistik nonparametrik dapat digunakan pada data dengan skala nominal, ordinal, interval maupun rasio.

Teknik analisis statistika inferensial dalam studi ini mencakup teknik analisis korelasi dan regresi (Pearson Product Moment, Path Analysis, Structural Equation Modeling/SEM), teknik

\footnotetext{
${ }^{17}$ Winkel. Psikologi Pengajaran. Jakarta: Gramedia Pustaka Utama Indonesia, 2007), h. 68

${ }^{18}$ Hamzah B. Uno. Teori Motivasi \& Pengukurannya: Analisis di Bidang Pendidikan. (Jakarta: Bumi Aksara, 2011).

${ }_{19}$ Burhan, "Kemampuan Analisis Statistik Inferensial Mahasiswa STAIN Sultan Qaimuddin Kendari Berbasis Gender", Jurnal Al Izzah, Vol. 8, No. 2 November 2013.

${ }^{20}$ Walpole, R.E., Pengantar Statistika, (Jakarta. Gramedia Pustaka Utama, 1995)

${ }^{21}$ Kadir, Statistika Untuk Penelitian Ilmu-Ilmu Sosial. (Jakarta: Rosemata Sampurna, 2010), h. 164
} 
analisis komparatif (t-test, anova, dan Anacova), serta teknik analisis lain tergantung tujuan penelitian.

Analisis statistik inferensial yang diteliti terkait dengan pengetahuan tentang (1) defenisi analisis statistika inferensial, (2) uji persyaratan analisis meliputi uji normalitas data baik dengan menggunakan rumus kemiringan/kemencengan kurva, maupun dengan menggunakan rumus chi kuadrat, (3) Mencari hubungan antara dua atau lebih variabel dengan menggunakan persamaan regresi linear sederhana untuk dua variabel dan persamaan regresi linear berganda untuk variabel lebih dari dua, (4) mencari besarnya sumbangan variabel dalam membentuk hubungan antar variabel dengan menggunakan koefisien determinasi, (5) uji hipotesis penelitian. ${ }^{22}$

Dengan demikian kemampuan analisis statistika inferensial meliputi tingkat pengetahuan atau pemahaman statistika yang dimiliki mahasiswa dalam melakukan pengolahan dan analisis data secara kuantitatif, dapat berupa kemampuan melakukan analisis sttistika deskriptif yang meliputi menghitung rerata, median, modus, standar deviasi, distribusi frekuensi, persentase dan kategorisasi, dan memiliki kemampuan melakukan analisis statistika inferensial yang meliputi pengujian asumsi (persyaratan analisis), dan pengujian hipotesis, yakni analisis korelasi, regresi linear, uji signifikansi, dan uji komparasi.

\section{E. Gambaran Perolehan Data}

Studi ini berupaya mengeksplorasikan data yang masuk dalam kategori penelitian korelasional dan berdasarkan sifat data termasuk penelitian assosiatif ex poss facto dengan tujuan untuk mencari pengaruh antara variabel exogen dan endogen. Penelitian ini dilaksanakan di FTIK IAIN Kendari pada mahasiswa semester VI Program Studi Pendidikan Agama Islam Tahun Akademik 2016/2017. Populasi dan sampel difokuskan kepada 54 orang mahasiswa yang telah lulus mata kuliah statistika dan metodologi penelitian. Instrumen yang digunakan adalah tes, kuesioner dan studi dokumentasi. Teknik analisis data yang digunakan adalah analisis deskriptif dan inferensial setelah memenuhi uji persyaratan normalitas, lineariitas, multikolinearitas dan autokorelasi. Pengujian hipotesis digunakan uji regresi linear, regresi ganda atau path analysis. ${ }^{23}$ Proses perhitungannya menggunakan Software IBM SPSS Statistics 20 for Windows.

Dalam penelitian ini terdapat empat variabel penelitian, masing-masing tiga variabel bebas, yaitu respon mahasiswa terhadap kompetensi dosen $\left(\mathrm{X}_{1}\right)$, motivasi belajar $\left(\mathrm{X}_{2}\right)$, sikap belajar mahasiswa $\left(\mathrm{X}_{3}\right)$, dan satu varibel terikat, yaitu; kemampuan analisis inferensial mahasiswa $(\mathrm{Y})$ pada Program Studi Pendidikan Agama Islam (PAI) di Fakultas Tarbiyah dan Ilmu Keguruan (FTIK) IAIN Kendari.

\section{F. Hubungan antara Kompetensi Dosen, Motivasi Belajar, Sikap Belajar, dan Analisis Kemampuan Inferensial Mahasiswa}

Berdasarkan data hasil penelitian yang diperoleh, maka gambaran data variabel kompetensi dosen, motivasi belajar, sikap belajar mahasiswa, dan satu varibel terikat, yaitu; kemampuan analisis inferensial mahasiswa dapat dideskripsikan berdasarkan masing-masing variabel penelitian pada tabel berikut:

Tabel 1; Deskripsi Data Hasil Penelitian (Variabel $\mathrm{X}_{1}, \mathrm{X}_{2}$ dan Y)

\begin{tabular}{llrrr} 
& \multicolumn{4}{c}{ Variabel Penelitian } \\
\multicolumn{2}{c}{ Parameter Statistik } & $\mathrm{X}_{1}$ & $\mathrm{X}_{2}$ & $\mathrm{Y}$ \\
\hline $\mathrm{N} \quad$ Valid & & 54 & 54 & 54
\end{tabular}

\footnotetext{
${ }^{22}$ Sony Sunaryo, dkk, Sejarah Perkembangan Statistika dan Aplikasinya, (Bogor, Jurusan Statistika IPB, tth).

${ }^{23}$ Sony Sunaryo, dkk, Sejarah Perkembangan Statistika dan Aplikasinya, h. 337
} 
Al Izzah: Jurnal Hasil-Hasil Penelitian-ISSN: 1978-9726 (p); 2541-0717 (e)

Volume 13, Nomor 1 (Mei, 2018)

\begin{tabular}{lrrr} 
Missing & 0 & 0 & 0 \\
Mean & 87.44 & 88.24 & 80.82 \\
Median & 87.50 & 90.00 & 79.00 \\
Mode & $85.00^{\mathrm{a}}$ & $95.00^{\mathrm{a}}$ & 78.00 \\
Std. Deviation & 5.827 & 7.726 & 6.628 \\
Variance & 33.950 & 59.696 & 43.927 \\
Range & 26.00 & 28.00 & 31.00 \\
Minimum & 73.00 & 70.00 & 65.00 \\
Maximum & 99.00 & 98.00 & 96.00 \\
Sum & 4722.00 & 4765.00 & 4364.00 \\
\hline Sumber: Hasil Pengolahan Data dengan SPSS Versi 20
\end{tabular}

\section{F.1 Pengujian Persyaratan Analisis}

\section{F.1.a Uji Normalitas Data}

Hasil uji normalitas menggunakan SPSS versi 20, yang hasilnya sebagai berikut:

Tabel 2; Hasil Uji Normalitas Data dengan Kolmogorov-Smirnov

\begin{tabular}{|lc|r|r|r|}
\hline \multicolumn{2}{|c|}{ Statistic } & \multicolumn{1}{|c|}{$\mathrm{X}_{1}$} & \multicolumn{1}{|c|}{$\mathrm{X}_{2}$} & \multicolumn{1}{c|}{$\mathrm{Y}$} \\
\hline \multirow{2}{*}{$\mathrm{N}$} & 54 & 54 & 54 \\
Normal & Mean & 87.44 & 88.24 & 80.82 \\
Parameters ${ }^{\mathrm{a}, \mathrm{b}}$ & $\quad$ Std. Deviation & 5.827 & 7.726 & 6.628 \\
\multirow{2}{*}{ Most Extreme } & Absolute & .087 & .127 & .163 \\
Differences & Positive & .061 & .103 & .163 \\
& Negative & -.087 & -.127 & -.083 \\
Kolmogorov-Smirnov Z & .637 & .934 & 1.201 \\
Asymp. Sig. (2-tailed) & $\mathbf{. 8 1 1}$ & $\mathbf{. 3 4 8}$ & $\mathbf{. 1 1 2}$ \\
\hline
\end{tabular}

a. Predictors: (Constant), X.1, X.2

b. Dependent Variable: Y

Sumber: Output Hasil Pengujian SPSS-20

Berdasarkan hasil output SPSS 20 pada tabel tersebut menunjukkan bahwa variabel kompetensi dosen $\left(\mathrm{X}_{1}\right)$ diperoleh nilai Sig. 0,811, motivasi belajar $\left(\mathrm{X}_{2}\right)$ dengan Sig. 0,348, dan kemampuan analisis inferensial mahasiswa (Y) dengan nilai Sig. 0,112, maka secara keseluruhan lebih besar dari $\alpha=0,05$, sehingga seluruh variabel yang digunakan dalam penelitian ini mempunyai sebaran data yang berdisitribusi normal.

\section{F.1.b Uji Linearitas Data}

Hasil pengujian Test for Linearity untuk variabel kompetensi dosen terhadap kemampuan analisis inferensial dengan menggunakan bantuan SPSS-20, sebagai berikut:

Tabel 3; Hasil Test for Linearity Variabel Kompetensi Dosen terhadap Kemampuan Analisis Inferensial Mahasiswa

\begin{tabular}{|c|c|c|c|c|c|c|c|}
\hline & & & $\begin{array}{l}\text { Sum of } \\
\text { Squares }\end{array}$ & $\mathrm{df}$ & $\begin{array}{l}\text { Mean } \\
\text { Square }\end{array}$ & $\mathrm{F}$ & Sig. \\
\hline $\mathrm{Y} * \mathrm{X}_{1}$ & $\begin{array}{l}\text { Between } \\
\text { Groups }\end{array}$ & $\begin{array}{l}\text { Deviation from } \\
\text { Linearity }\end{array}$ & 781.360 & 20 & 39.068 & .874 & .617 \\
\hline $\mathrm{Y} * \mathrm{X}_{2}$ & $\begin{array}{l}\text { Between } \\
\text { Groups }\end{array}$ & $\begin{array}{l}\text { Deviation from } \\
\text { Linearity }\end{array}$ & 451.602 & 18 & 25.089 & .918 & .564 \\
\hline
\end{tabular}


Berdasarkan hasil uji linearitas data pada tabel tersebut bahwa nilai signifikansi dari Defiation From Linierity masing-masing variabel, yakni kompetensi dosen $\left(\mathrm{X}_{1}\right)$ adalah 0,617 dan motivasi belajar $\left(\mathrm{X}_{2}\right)$ adalah 0,564 lebih besar dari $\alpha=0,05$ sehingga disimpulkan bahwa garis regresi variabel tersebut berbentuk linear sehingga bisa digunakan untuk memprediksi besarnya variabel kemampuan analisis inferensial mahasiswa Program Studi Pendidikan Agama Islam (PAI) di Fakultas Tarbiyah dan Ilmu Keguruan (FTIK) IAIN Kendari.

\section{F.1.c Uji Muiltikolinearitas Data}

Hasil pengujian multikolinieritas dalam regresi antara variabel bebas kompetensi dosen $\left(\mathrm{X}_{1}\right)$ dan motivasi belajar $\left(\mathrm{X}_{2}\right)$ terhadap variabel terikat yaitu kemampuan analisis statistik inferensial (Y). Data hasil pengolahan data penelitian tersebut adalah sebagai berikut:

Tabel 4; Hasil Pengujian Muiltikolinearitas

\begin{tabular}{cccc}
\hline \multicolumn{2}{c}{ Model } & \multicolumn{2}{c}{ Collinearity Statistics } \\
\multicolumn{2}{c}{ Tolerance } & VIF \\
\hline \multirow{2}{*}{1} & X.1 & .629 & 1.189 \\
& X.2 & .562 & 1.279 \\
\hline a. Dependent Variable: Y & & \\
Sumber: Output Hasil Pengujian & SPSS-20
\end{tabular}

Ternyata nilai VIF mendekati 1 untuk semua variabel bebas. Demikian pula, nilai tolerance mendekati 1 untuk semua variabel bebas. Dengan demikian, dapat disimpulkan bahwa dalam regresi antara variabel bebas kompetensi dosen $\left(\mathrm{X}_{1}\right)$, dan motivasi belajar $\left(\mathrm{X}_{2}\right)$ terhadap variabel terikat yaitu kemampuan analisis statistik inferensial $(\mathrm{Y})$ tidak terjadi multikolinieritas antar variabel bebas.

\section{F.1.d Uji Autokorelasi Data}

Dalam penelitian ini, penulis menggunakan uji Durbin Watson, yang mana dalam hasil pengujian menunjukkan bahwa dalam penelitian ini tidak terjadi Aulokorelasi antara variabel bebas (kompetensi dosen, motivasi belajar dan sikap mahasiswa terhadap variabel dependen (kemampuan analisis statistik inferensial). Hasil pengujian autokorelasi dapat dilihat pada tabel berikut ini:

Tabel 5; Hasil Pengujian Autokorelasi

\begin{tabular}{lccrrr}
\hline Model & $\mathrm{R}$ & $\mathrm{R}$ Square & $\begin{array}{c}\text { Adjusted R } \\
\text { Square }\end{array}$ & $\begin{array}{c}\text { Std. Error of the } \\
\text { Estimate }\end{array}$ & Durbin-Watson \\
\hline 1 & $.789^{\mathrm{a}}$ & .622 & .609 & 3.90654 & 2.137 \\
\hline a. Predictors: (Constant), X.1, X.2 & & & \\
b. Dependent Variable: Y & & & \\
Sumber: Output Hasil Pengujian SPSS-20 & & &
\end{tabular}

Ternyata koefisien Durbin-Watson besarnya 2,137, mendekati 2. Dengan demikian, dapat disimpulkan bahwa dalam regresi antara variabel bebas kompetensi dosen $\left(\mathrm{X}_{1}\right)$, motivasi belajar $\left(\mathrm{X}_{2}\right)$, dan sikap mahasiswa $\left(\mathrm{X}_{3}\right)$ terhadap variabel terikat yaitu kemampuan analisis statistik inferensial (Y) tidak terjadi autokorelasi.

\section{F.2 Hasil Pengujian Secara Parsial}

\section{F.2.a Pengaruh kompetensi dosen terhadap kemampuan ananalisis inferensial Mahasiswa}


Hasil pengujian hipotesis secara parsial pengaruh kompetensi dosen terhadap kemampuan analisis inferensial mahasiswa sebagaimana hasil pengolahan data dapat dilihat pada tabel berikut:

Tabel 6; Hasil Analisis Regresi Secara Parsial

\begin{tabular}{|c|c|c|c|c|c|c|}
\hline & \multirow{2}{*}{ Model } & \multicolumn{2}{|c|}{ Unstandardized Coefficients } & $\begin{array}{l}\text { Standardized } \\
\text { Coefficients }\end{array}$ & \multirow[t]{2}{*}{$\mathrm{t}$} & \multirow{2}{*}{ Sig. } \\
\hline & & B & Std. Error & Beta & & \\
\hline & (Constant) & 23.195 & 6.267 & & 3.701 & .000 \\
\hline 1 & $\mathrm{X}_{1}$ & .697 & .072 & .780 & 9.662 & .000 \\
\hline
\end{tabular}

a. Dependent Variable: Y

Sumber: Output Hasil Pengujian SPSS-20

Berdasarkan tebel coefficients di atas, menjelaskan bahwa persamaan regresinya $Y^{\prime}=a+b$ $\mathrm{X}_{1}$ adalah $\mathrm{Y}^{\prime}=23,195+0,697 \mathrm{X}_{1}$. Selanjutnya pada nilai signifikansi (Sig.) baik skor konstan dan beta diperoleh nilai Sig. $=0,000<\alpha=0,05$, yang berarti bahwa kompetensi dosen berpengaruh terhadap kemampuan analisis inferensial mahasiswa.

Selanjutnya untuk melihat signifikansi regresi linear variabel kompetensi dosen terhadap kemampuan analisis inferensial mahasiswa, dijelaskan berdasarkan tabel berikut:

Tabel 7; Uji Anova Variabel $\mathrm{X}_{1}$ terhadap Y

\begin{tabular}{rlrrrrr}
\hline & \multicolumn{7}{c}{ ANOVA $^{\mathrm{a}}$} & & & \\
\hline \multirow{2}{*}{ Model } & Sum of & df & Mean Square & \multicolumn{1}{c}{ F } & Sig. \\
\hline \multirow{2}{*}{1} & Regression & 1450.831 & 1 & 1450.831 & 93.349 & $.000^{\mathrm{b}}$ \\
& Residual & 932.524 & 60 & 15.542 & & \\
& Total & 2383.355 & 61 & & & \\
\hline
\end{tabular}

a. Dependent Variable: $\mathrm{Y}$

b. Predictors: (Constant), $\mathrm{X}_{1}$

Sumber: Output Hasil Pengujian SPSS-20

Tabel di atas menunjukkan bahwa hasil pengujian hipotesis berdasarkan Output ANOVA diperoleh nilai $\operatorname{Sig}=0,000<\alpha=0,05$, maka dapat disimpulkan bahwa kompetensi dosen berpengaruh signifikan terhadap kemampuan analisis inferensial mahasiswa.

Selanjutnya untuk mengetahui koefisien determinasi atau besarnya kontribusi variabel $\mathrm{X}_{1}$ terhadap Y, maka dapat dilihat pada tabel koefisien regresi sebagai berikut:

Tabel 8; Uji Koefisien Determinasi Variabel $\mathrm{X}_{1}$ terhadap $\mathrm{Y}$

\begin{tabular}{ccccc}
\hline Model & $\mathrm{R}$ & $\mathrm{R}$ Square & $\begin{array}{c}\text { Adjusted R } \\
\text { Square }\end{array}$ & $\begin{array}{c}\text { Std. Error of the } \\
\text { Estimate }\end{array}$ \\
\hline 1 & $.780^{\mathrm{a}}$ & .609 & \multicolumn{6}{c}{.602} & 3.94234 \\
\hline a. Predictors: (Constant), $\mathrm{X}_{1}$ & & & \\
Sumber: Output Hasil Pengujian SPSS-20 &
\end{tabular}

Berdasarkan tabel di atas, maka koefisien determinasi $\left(\mathrm{R}^{2}\right)$ adalah sebesar 0,609 yang berarti bahwa kompetensi dosen berkontribusi terhadap kemampuan analaisis inferensial mahasiswa sebesar $60,9 \%$.

\section{F.2.b Pengaruh Motivasi Belajar terhadap Kemampuan Analisis Inferensial Mahasiswa}

Hasil pengujian hipotesis secara parsial pengaruh motivasi belajar terhadap kemampuan analisis inferensial mahasiswa sebagaimana hasil pengolahan data dapat dilihat pada tabel berikut:

Tabel 9; Hasil Analisis Regresi Secara Parsial 


\begin{tabular}{|c|c|c|c|c|c|c|}
\hline & \multirow{2}{*}{ Model } & \multicolumn{2}{|c|}{ Unstandardized Coefficients } & $\begin{array}{l}\text { Standardized } \\
\text { Coefficients }\end{array}$ & \multirow[t]{2}{*}{$\mathrm{t}$} & \multirow[t]{2}{*}{ Sig. } \\
\hline \multirow{3}{*}{1} & & $\mathrm{~B}$ & Std. Error & Beta & & \\
\hline & (Constant) & 34.683 & 7.933 & & 4.372 & .000 \\
\hline & $\mathrm{X}_{2}$ & .555 & .090 & .624 & 6.179 & .000 \\
\hline
\end{tabular}

a. Dependent Variable: $\mathrm{Y}$

Sumber: Output Hasil Pengujian SPSS-20

Berdasarkan tebel coefficients di atas, menjelaskan bahwa persamaan regresinya $\mathrm{Y}^{\prime}=\mathrm{a}+\mathrm{bX} 2$ adalah $\mathrm{Y}^{\prime}=34,683+0,555 \mathrm{X}_{2}$. Selanjutnya pada nilai signifikansi (Sig.) baik skor konstan dan beta diperoleh nilai Sig. $=0,000<\alpha=0,05$, yang berarti bahwa motivasi belajar berpengaruh terhadap kemampuan analisi inferensial mahasiswa.

Selanjutnya untuk melihat signifikansi regresi linear variabel motivasi belajar terhadap kemampuan analisis inferensial mahasiswa, dijelaskan berdasarkan tabel berikut:

Tabel 10; Uji Anova Variabel $\mathrm{X}_{2}$ terhadap Y

\begin{tabular}{|c|c|c|c|c|c|c|}
\hline & Model & Sum of Squares & $\mathrm{df}$ & Mean Square & $\mathrm{F}$ & Sig. \\
\hline \multirow{3}{*}{1} & Regression & 926.865 & 1 & 926.865 & 38.182 & $.000^{\mathrm{b}}$ \\
\hline & Residual & 1456.490 & 60 & 24.275 & & \\
\hline & Total & 2383.355 & 61 & & & \\
\hline
\end{tabular}

a. Dependent Variable: Y

b. Predictors: (Constant), $\mathrm{X}_{2}$

Sumber: Output Hasil Pengujian SPSS-20

Tabel tersebut menunjukkan bahwa hasil pengujian hipotesis berdasarkan Output ANOVA diperoleh nilai Sig $=0,000<\alpha=0,05$, maka dapat disimpulkan bahwa motivasi belajar berpengaruh signifikan terhadap kemampuan analisis inferensial mahasiswa.

Selanjutnya untuk mengetahui koefisien determinasi atau besarnya kontribusi variabel $\mathrm{X}_{2}$ terhadap Y, maka dapat dilihat pada tabel koefisien regresi sebagai berikut:

Tabel 11; Uji Koefisien Determinasi Variabel $\mathrm{X}_{1}$ terhadap Y

\begin{tabular}{ccccc}
\hline Model & $\mathrm{R}$ & R Square & $\begin{array}{c}\text { Adjusted R } \\
\text { Square }\end{array}$ & $\begin{array}{c}\text { Std. Error of the } \\
\text { Estimate }\end{array}$ \\
\hline 1 & $.624^{\mathrm{a}}$ & .389 & .379 & 4.92695 \\
\hline a. Predictors: (Constant), $\mathrm{X}_{2}$ & & & \\
Sumber: Output Hasil Pengujian SPSS-20 & &
\end{tabular}

Berdasarkan tabel di atas, maka koefisien determinasi $\left(\mathrm{R}^{2}\right)$ adalah sebesar 0,389 yang berarti bahwa motivasi belajar berkontribusi terhadap kemampuan analaisis inferensial mahasiswa sebesar $38,9 \%$.

\section{F.3 Hasil Pengujian Secara Simultan}

\section{F.3.a Pengaruh Kompetensi Dosen Dan Motivasi Belajar Terhadap Kemampuan Ananalisis Inferensial Mahasiswa}

Hasil pengujian hipotesis secara simultan tentang pengaruh kompetensi dosen dan motivasi belajar terhadap kemampuan analisis inferensial mahasiswa sebagaimana hasil pengolahan data dapat dilihat pada tabel berikut:

Tabel 12; Hasil Analisis Regresi Secara Simultan

\begin{tabular}{|c|c|c|c|c|}
\hline Model & Unstandardized Coefficients & $\begin{array}{l}\text { Standardized } \\
\text { Coefficients }\end{array}$ & $\mathrm{t}$ & Sig. \\
\hline (Constant) & $\begin{array}{lr}\text { B } & \text { Std. Error } \\
19.201 & 6.793\end{array}$ & Beta & 2.827 & .006 \\
\hline
\end{tabular}




\begin{tabular}{rlllll}
$\mathrm{X}_{1}$ & .598 & .099 & .669 & 6.036 & .000 \\
$\mathrm{X}_{2}$ & .431 & .099 & .161 & 3.451 & .015 \\
\hline
\end{tabular}

a. Dependent Variable: $\mathrm{Y}$

Sumber: Output Hasil Pengujian SPSS-20

Berdasarkan tebel coefficients di atas, menjelaskan bahwa persamaan regresinya $\mathrm{Y}^{\prime}=\mathrm{a}+\mathrm{bX} \mathrm{X}_{1+} \mathrm{bX}_{2}$ adalah $\mathrm{Y}^{\prime}=19,201+0,598 \mathrm{X}_{1}+0,431 \mathrm{X}_{2}$. Selanjutnya pada nilai signifikansi (Sig.) baik skor konstan dan beta diperoleh nilai Sig. $=0,000<\alpha=0,05$, yang berarti bahwa kompetensi dosen dan motivasi belajar berpengaruh terhadap kemampuan analisi inferensial mahasiswa.

Selanjutnya untuk melihat signifikansi regresi linear berganda pada variabel kompetensi dosen dan motivasi belajar terhadap kemampuan analisis inferensial mahasiswa, dijelaskan berdasarkan tabel berikut:

Tabel 4.13 Uji Anova Variabel $\mathrm{X}_{2}$ dan $\mathrm{X}_{2}$ terhadap Y

\begin{tabular}{rlrrrrr}
\hline & Model & Sum of Squares & Df & Mean Square & F & \multicolumn{1}{c}{ Sig. } \\
\hline \multirow{2}{*}{1} & Regression & 1482.954 & 2 & 741.477 & 48.586 & $.000^{\mathrm{b}}$ \\
\cline { 2 - 7 } & Residual & 900.401 & 59 & 15.261 & & \\
\cline { 2 - 6 } & Total & 2383.355 & 61 & & & \\
\hline
\end{tabular}

a. Dependent Variable: Y

b. Predictors: (Constant), $\mathrm{X}_{2}, \mathrm{X}_{1}$

Sumber: Output Hasil Pengujian SPSS-20

Tabel tersebut menunjukkan bahwa hasil pengujian hipotesis berdasarkan Output ANOVA diperoleh nilai $\operatorname{Sig}=0,000<\alpha=0,05$, maka dapat disimpulkan bahwa kompetensi dosen dan motivasi belajar berpengaruh signifikan terhadap kemampuan analisis inferensial mahasiswa.

Selanjutnya untuk mengetahui koefisien determinasi atau besarnya kontribusi variabel $\mathrm{X}_{1}$ dan $\mathrm{X}_{2}$ terhadap $\mathrm{Y}$, maka dapat dilihat pada tabel koefisien regresi sebagai berikut:

Tabel 4.14 Uji Koefisien Determinasi Variabel $\mathrm{X}_{1}$ terhadap Y

\begin{tabular}{|c|c|c|c|c|}
\hline Model & $\mathrm{R}$ & R Square & $\begin{array}{c}\text { Adjusted R } \\
\text { Square }\end{array}$ & $\begin{array}{l}\text { Std. Error of the } \\
\text { Estimate }\end{array}$ \\
\hline 1 & $.789^{\mathrm{a}}$ & .622 & .609 & 3.90654 \\
\hline
\end{tabular}

Berdasarkan tabel di atas, maka koefisien determinasi $\left(\mathrm{R}^{2}\right)$ adalah sebesar 0,622 yang berarti bahwa kompetensi dosen dan motivasi belajar berkontribusi secara bersama-sama terhadap kemampuan analaisis inferensial mahasiswa sebesar $62,2 \%$.

\section{F.3.b Pengaruh Variabel $X_{1}$ terhadap Variabel $Y$}

Hasil penelitian dan uji hipotesis menunjukkan bahwa kompetensi dosen $\left(\mathrm{X}_{1}\right)$ berpengaruh signifikan terhadap kemampuan analisis inferensial mahasiswa $(\mathrm{Y})$ pada program studi PAI di FTIK IAIN Kendari. Hal ini dibuktikan dengan nilai signifikansi $(\rho)=0,000$ lebih kecil dari $\alpha$ $=0,05$, dengan persamaan regresi diperoleh $\mathrm{Y}=23,195+0,697 \mathrm{X}_{1}$, artinya setiap kenaikan satu skor kompetensi dosen dalam memberikan perkuliahan statistik maka akan menyebabkan kenaikan 0,697 skor kemampuan analisis statistik inferensial mahasiswa pada konstanta 23,195. Hal tersebut menunjukkan bahwa kompetensi dosen berpengaruh yang signifikan terhadap kemampuan analisis inferensial mahasiswa. Besarnya kontribusi kompetensi dosen terhadap kemampuan analaisis inferensial mahasiswa adalah sebesar $60,9 \%$.

Temuan di atas menujukkan bahwa kompetensi mengajar dosen menjadi sangat urgen dalam peningkatan pemahaman mahasiswa terhadap materi pembelajaran. Untuk mampu melaksanakan tugas mengajar dengan baik, dosen harus memiliki kemampuan profesional. Dosen adalah pendidik profesional dan ilmuwan dengan tugas utama mentransformasikan, 
mengembangkan dan menyebarluaskan ilmu pengetahuan, teknologi, dan seni melalui pendidikan, penelitian dan pengabdian kepada masyarakat. ${ }^{24}$

Hasil penelitian ini sejalan pula dengan hasil penelitian Suarjana dan Yintayani, bahwa kompetensi pedagogik, profesional, kepribadian dan sosial secara simultan berpengaruh positif dan signifikan terhadap prestasi belajar mahasiswa, yang berarti bahwa jika keempat kompetensi tersebut semakin baik/meningkat, maka akan meningkatkan prestasi belajar mahasiswa pada Jurusan Akuntansi Politeknik Negeri Bali dengan kontribusi pengaruh kompetensi dosen terhadap prestasi belajar mahasiswa sebesar $95 \%{ }^{25}$.

Berkaitan dengan hal tersebut, pemahaman statistik mahasiswa terhadap kemampuan melakukan analisis inferensial untuk keperluan penelitian dapat terpenuhi apabila semua unsurunsur pembelajaran saling mendukung satu sama lain. Salah satu unsur yang terkait adalah pemenuhan kompetensi dosen yang mengajar statistik, seperti dosen yang mengajar harus sesuai dengan kompetensi jurusannya, memiliki integritas untuk meningkatkan potensi mengajarnya, senantiasa meningkatkan kinerjanya dalam berbagai bidang kajian penelitian sehingga dapat memiliki pengalaman-pengalaman riset yang bervariasi dan berdampak pada kecenderungan mahasiswa untuk membaca hasil-hasil riset dosen yang bersangkutan.

\section{F.3.c Pengaruh Variabel $X_{2}$ terhadap Variabel $Y$}

Hasil penelitian dan uji hipotesis menunjukkan bahwa motivasi belajar $\left(\mathrm{X}_{2}\right)$ berpengaruh signifikan terhadap kemampuan analisis inferensial mahasiswa $(\mathrm{Y})$ pada program studi PAI di FTIK IAIN Kendari. Hal ini dibuktikan dengan nilai signifikansi $(\rho)=0,000$ lebih kecil dari $\alpha$ $=0,05$, dengan persamaan regresi diperoleh $\mathrm{Y}=34,683+0,555 \mathrm{X}_{2}$, artinya setiap kenaikan satu skor motivasi belajar dalam perkuliahan statistik maka akan menyebabkan kenaikan 0,555 skor kemampuan analisis statistik inferensial mahasiswa pada konstanta 34,683. Besarnya kontribusi motivasi belajar terhadap kemampuan analaisis inferensial mahasiswa adalah sebesar 38,9\%.

Temuan tersebut menunjukkan bahwa motivasi belajar mahasiswa dalam perkuliahan statistik menjadi penyebab tinggi atau rendahnya kemampuan analisis inferensial mahasiswa. Motivasi belajar dapat menjadi tinggi apabila faktor-faktor yang mempengaruhinya juga terpenuhi. Semakin tinggi motivasi belajar seorang siswa maka semakin tinggi pula kemungkinan siswa tersebut berhasil dalam mata pelajaran yang dipelajarinya. Motivasi belajar dipengaruhi oleh beberapa faktor, salah satu faktor tersebut adalah kemampuan mengajar yang dimiliki oleh dosen. Hal ini sejalan dengan hasil penelitian Nanik Suherni, bahwa kompetensi dosen berpengaruh dalam meningkatkan motivasi belajar mahasiswa di Universitas Widyatama Bandung. Motivasi mahasiswa kurang dikarenakan oleh beberapa faktor, diantaranya ketidakpuasan dalam proses belajar mengajar yang dilakukan dosen, dan kualitas mahasiswa itu sendiri tergolong rendah. ${ }^{26}$

Dalam interaksi antara dosen dan mahasiswa sering kali timbul masalah, yaitu adanya keluhan dari mahasiswa tentang cara atau teknik mengajar dosen. Termasuk juga kompetensi dosen yang terdiri dari kompetensi pedagogik, kompetensi profesional, kompetensi sosial dan kompetensi personal yang belum secara keseluruhan diterapkan dosen dalam proses belajar mengajar, Dampak dari permasalahan tersebut, mahasiswa tidak hadir kuliah dengan alasan yang tidak jelas, tidak memperhatikan dan bahkan mahasiswa sering berbicara dengan temannya sehingga membuat gaduh atau ramai.

\footnotetext{
${ }^{24}$ Dwi Budiadi, Pengaruh Kompetensi Dosen, Self Efficacy, Locus of Control, Fasilitas Pembelajaran terhadap Tingkat Pemahaman Mahasiswa Akuntansi, Jurnal Cahaya Aktiva Vol.2 No. 1, 2013

${ }^{25}$ Suarjana, Mantra, A.G. dan Ni Nyoman Yintayani, Pengaruh Kompetensi Dosen terhadap prestasi belajar Mahasiswa. Jurnal Bisnis dan Kewirausahaan Vol 13 No. 2 Juli 2017

${ }^{26}$ Nanik Seherni, Pengaruh Kompetensi Dosen terhadap Motivasi Belajar Mahasiswa. Tesis di Universitas Widyatama Bandung, 2014
} 
Apabila dosen yang mengajar memiliki kompetensi mengajar yang baik, misalnya mengusai materi, memilki strategi pembelajaran dan pengelolaan kelas yang baik, maka mahasiswa yang diajar akan memiliki motivasi untuk senantiasa hadir mengikuti perkuliahan dan akan mudah mengerti pada materi yang diajarkan sehingga mahasiswa merasa termotivasi untuk belajar dan merasa puas. Kepuasan mahasiswa akan berdampak pada prestasi mahasiswa yang ditunjukkan dengan indeks prestasi mahasiswa.

\section{F.3.d Pengaruh Variabel $X_{1}$, dan $X_{2}$ terhadap Variabel $Y$}

Hasil penelitian dan uji hipotesis menunjukkan bahwa kompetensi dosen $\left(\mathrm{X}_{1}\right)$ dan motivasi belajar $\left(\mathrm{X}_{2}\right)$ secara bersama-sama berpengaruh signifikan terhadap kemampuan analisis inferensial mahasiswa (Y) pada program studi PAI di FTIK IAIN Kendari. Hal ini dibuktikan dengan nilai signifikansi $(\rho)=0,000$ lebih kecil dari $\alpha=0,05$, dengan persamaan regresi diperoleh $\mathrm{Y}=19,201+0,598 \mathrm{X}_{1}+0,431 \mathrm{X}_{2}$, artinya setiap kenaikan satu skor motivasi belajar dalam perkuliahan statistik maka akan menyebabkan kenaikan 0,555 skor kemampuan analisis statistik inferensial mahasiswa pada konstanta 19,201. Besarnya kontribusi kompetensi dosen dan motivasi belajar terhadap kemampuan analaisis inferensial mahasiswa secara bersamasama adalah sebesar 38,9\%.

Temuan tersebut di atas menunjukkan bahwa kompetensi yang dimiliki dosen berperan serta dalam meningkatkan motivasi belajar mahasiswa dan dapat menciptakan sikap dan perilaku positif mahasiswa dalam mengikuti perkuliahan statistik. Hal ini sejalan dengan hasil penelitian Elis Mediawati, bahwa motivasi belajar mahasiswa dan kompetensi dosen memiliki pengaruh positif dan signifikan baik secara parsial maupun simultan terhadap prestasi belajar mahasiswa. Dosen yang mempunyai kompetensi yang baik akan menjadikan suatu proses belajar yang optimal dan efisien yang pada akhirnya dapat meningkatkan prestasi belajar. ${ }^{27}$

Dengan motivasi belajar yang tinggi dimiliki oleh mahasiswa tercipta karena kompetensi dosen sehingga dosen menjadi profesional dalam mengelola pembelajaran dan dapat mengakibatkan kemampuan analisis inferensial mahasiswa dapat meningkat. Kompetensi adalah kemampuan, kecakapan dan keterampilan yang dimiliki seseorang berkenaan dengan tugas jabatan maupun profesinya" 28

Makna dari perihal tersebut menunjukkan bahwa terdapat hubungan yang saling berkaitan dan saling memberi pengaruh antara kompetensi yang ditunjukkan dosen terhadap motivasi dan kinerja. Sementara dalam penelitian ini kompetensi dosen dan motivasi belajar mahasiswa yang memberikan pengaruh positif dan signifikan terhadap kemampuan analisis inferensial mahasiswa yang berarti bahwa setiap dosen telah menunjukkan kompetensinya baik kompetensi pedagogik, profesional, kepribadian, dan sosial dalam menyelenggarakan pembelajaran statistik. Hal ini sesuai dengan isi UU No. 14 tahun 2005 tentang Guru dan Dosen. ${ }^{29}$ Kompetensi adalah seperangkat pengetahuan, ketrampilan, dan perilaku yang harus dimiliki, dihayati dan dikuasai oleh guru atau dosen dalam melaksanakan tugas keprofesionalan.

Dengan demikian, maka dari pembahasan di atas menunjukkan bahwa setiap dosen telah menunjukkan kompetensi pedagogik, profesional, kepribadian dan sosial dalam menjalankan kegiatan pembelajaran dengan baik, sehingga menyebabkan mahasiswa memiliki motivasi yang tinggi dalam mengikuti perkuliahan statistik. Namun masih tetap perlu untuk senantiasa berupaya meningkatkan kompetensi dosen, serta mendapatkan kewenangan kekuasaan untuk menunjukkan kepribadiannya menguasai bidang pengajarannya, sehingga motivasi dan hasil

\footnotetext{
${ }^{27}$ Elis Mediawati, Pengaruh Motivasi Belajar Mahasiswa Dan Kompetensi Dosen Terhadap Prestasi Belajar. Jurnal Pendidikan Ekonomi Dinamika Pendidikan Vol 5 No.2 Tahun 2010

${ }^{28}$ Trianto, dkk. Tinjauan Yuridis Hak serta Kewajiban Pendidik Menurut UU Guru dan Dosen. (Jakarta: Prestasi Pustaka, 2006).

${ }^{29}$ Undang-Undang Nomor 14 tahun 2005 tentang Guru dan Dosen
} 
belajar mahasiswa menjadi lebih baik.

\section{G. Penutup}

Kompetensi dosen secara parsial berpengaruh signifikan terhadap kemampuan analisis statistika inferensial mahasiswa pada program studi PAI di FTIK IANIN Kendari. Semakin tinggi kompetensi yang dimiliki dosen yang mengajar statistik, maka tingkat kemampuan analisis statistika inferensial mahasiswa juga dapat menjadi lebih tinggi.

Motivasi belajar secara parsial berpengaruh signifikan terhadap kemampuan analisis statistika inferensial mahasiswa pada program studi PAI di FTIK IAIN Kendari. Semakin tinggi motivasi belajar yang dimiliki mahasiswa pada mata kuliah statistik, maka tingkat kemampuan analisis statistika inferensial mahasiswa juga dapat lebih meningkat.

Kompetensi dosen dan motivasi belajar mahasiswa secara simultan berpengaruh signifikan terhadap kemampuan analisis statistika inferensial mahasiswa pada program studi PAI di FTIK IAIN Kendari. Kedua variabel tersebut memberikan kontribusi secara bersama-sama sebesar $62,2 \%$, sedangkan sisanya sebesar $37,8 \%$ dipengaruhi atau dijelaskan oleh faktor lain yang tidak dibahas dalam penelitian ini. Semakin tinggi kompetensi yang dimiliki dosen yang mengajar statistik dan motivasi belajar, maka kemampuan anlaisis statistika inferensial mahasiswa juga dapat semakin meningkat sehingga pengetahuan statistik yang dimiliki mahasiswa dapat dimanfaatkan untuk kepentingan penelitian dalan menyusun karya ilmiah atau skripsi.

\section{Daftar Pustaka}

Ahmadi, Abu dan Supriyono. Psikologi Belajar. Jakarta: Rineka Cipta, 2008

B. Uno, Hamzah. Teori Motivasi \& Pengukurannya: Analisis Di Bidang Pendidikan. (Jakarta: Bumi Aksara, 2011).

Budiadi, Dwi. "Pengaruh Kompetensi Dosen, Self Efficacy, Locus of Control, Fasilitas Pembelajaran terhadap Tingkat Pemahaman Mahasiswa Akuntansi”. Jurnal Cahaya Aktiva Vol.2 No. 1, 2013.

Burhan. "Kemampuan Analisis Statistik Inferensial Mahasiswa STAIN Sultan Qaimuddin Kendari Berbasis Gender”. Jurnal Al Izzah, Vol. 8, No. 2. November 2013.

Dimyati dan Murdjiono, Belajar dan Pembelajaran. Jakarta: PT. Rineka Cipta, 2009

Djaali. Psikologi Pendidikan. Jakarta: PT. Bumi Aksara, 2008

Djamarah, Syaiful Bahri dan Aswan Zain. Strategi Belajar Mengajar. Jakarta: Rineka Cipta, 2006.

Psikologi Belajar. Jakarta: Rineka Cipta, 2000.

Kadir. Statistika Untuk Penelitian Ilmu-Ilmu Sosial. Jakarta: Rosemata Sampurna, 2010.

Martinis, Yamin. Sertifikasi Profesi Keguruan di Indonesia. Jakarta: Gaung Persada Press, 2006.

Mediawati, Elis. "Pengaruh Motivasi Belajar Mahasiswa Dan Kompetensi Dosen Terhadap Prestasi Belajar”. Jurnal Pendidikan Ekonomi Dinamika Pendidikan. Vol 5 No.2, 2010.

Muhibbin, Syah. Psikologi Pendidikan dengan Pendekatan Baru. Bandung: Rosdakarya, 2004

Musfah, Jejen. Peningkatan Kompetensi Guru Melalui Pelatihan \& Sumber Belajar, Teori dan Praktik. Yogyakarta: Prenada Media Group, 2017.

Sardiman A.M. Interaksi dan Motivasi Belajar Mengajar. Jakarta: Rajawali Press, 2005.

Seherni, Nanik. Pengaruh Kompetensi Dosen terhadap Motivasi Belajar Mahasiswa. Tesis di Universitas Widyatama, Bandung, 2014 
Suarjana, Mantra, A.G. dan Ni Nyoman Yintayani. "Pengaruh Kompetensi Dosen terhadap Prestasi Belajar Mahasiswa". Jurnal Bisnis dan Kewirausahaan. Vol 13 No. 2 Juli 2017

Sunaryo, Sony dkk. Sejarah Perkembangan Statistika dan Aplikasinya. Bogor, Jurusan Statistika IPB, tth.

Trianto, dkk. Tinjauan Yuridis Hak serta Kewajiban Pendidik Menurut UU Guru dan Dosen. Jakarta: Prestasi Pustaka, 2006.

Walpole, R.E. Pengantar Statistika. Jakarta. Gramedia Pustaka Utama, 1995.

Winkel. Psikologi Pengajaran. Jakarta: Gramedia Pustaka Utama Indonesia, 2007. 